\title{
Productivity and quality of Formosa and Solo papaya over two harvest seasons
}

\author{
Fabíola Lacerda de Souza Barros ${ }^{(1)}$, Karin Tesch Kuhlcamp ${ }^{(1)}$, \\ Sara Dousseau Arantes ${ }^{(1)}$ and Sarah Ola Moreira(1)
}

\begin{abstract}
(1)Instituto Capixaba de Pesquisa, Assistência Técnica e Extensão Rural, Centro Regional de Desenvolvimento Rural Centro Norte, Rodovia BR 101, Km 151, CEP 29900-000 Linhares, ES, Brazil. E-mail: fabiola.barros@incaper.es.gov.br, karin.kuhlcamp@incaper.es.gov.br, sara.arantes@incaper.es.gov.br, sarah.moreira@incaper.es.gov.br
\end{abstract}

\begin{abstract}
The objective of this work was to evaluate the productivity and quality of papaya fruits (Carica papaya) of the Solo (12 genotypes) and Formosa (9 genotypes) heterotic groups over two harvest seasons. The experiment was conducted under field conditions in the municipality of Pinheiros, in the state of Espírito Santo, Brazil, in a randomized complete block design. Ten morpho-agronomic and physicochemical variables of the fruits were measured in winter (210-300 days after planting) and summer (450-540 days after planting). The data were subjected to the combined analysis of variance, to the breakdown of the genotype $\mathrm{x}$ environment interactions, and to the grouping of means by the Scott-Knott test. Although harvest season affected the evaluated characteristics, it did not alter the classification of the genotype. In the Solo group, the H 36-45 and UC 15 hybrids stand out due to their greater productivity, fruit weight, and soluble solids contents. In the Formosa group, the Rubi Incaper 511 cultivar shows greater productivity, higher number of commercial fruits, and lower number of deformed fruits over both evaluated harvest seasons.
\end{abstract}

Index terms: Carica papaya, agronomic performance, environmental effect, genotype evaluation.

\section{Produtividade e qualidade de frutos de mamão Formosa e Solo em duas épocas de colheita}

Resumo - O objetivo deste trabalho foi avaliar a produtividade e a qualidade de frutos de mamoeiro (Carica papaya) dos grupos heteróticos Solo (12 genótipos) e Formosa (9 genótipos), em duas épocas de colheita. O experimento foi conduzido em condições de campo em Pinheiros, ES, em delineamento de blocos ao acaso. Dez variáveis morfoagronômicas e físico-químicas dos frutos foram avaliadas no inverno (210 a 300 dias após o plantio) e no verão (450 a 540 dias após o plantio). Os dados foram submetidos à análise de variância conjunta, à decomposição da interação genótipo $\mathrm{x}$ ambiente e ao agrupamento das médias pelo teste de Scott-Knott. Embora a colheita em diferentes épocas tenha influenciado as características avaliadas, não alterou a classificação dos genótipos. No grupo Solo, destacam-se os híbridos H 36-45 e UC 15, por suas maiores produção e massa do fruto e por seu alto teor de sólidos solúveis. No grupo Formosa, a cultivar Rubi Incaper 511 apresenta maior produção, maior número de frutos comerciais e menor número de frutos deformados nas duas épocas de colheita avaliadas.

Termos para indexação: Carica papaya, desempenho agronômico, efeito ambiental, avaliação de genótipos.

\section{Introduction}

The demand for Brazilian papaya (Carica papaya L.) continues to increase in the international and domestic markets. However, the reduced number of available cultivars, the incidence of diseases, and the effect of climatic conditions on fruit development compromise the continuous growth in productivity (Moretti et al., 2010; Pinto et al., 2013b).

The main papaya cultivars grown in Brazil are Golden and Sunrise Solo, of the Solo heterotic group, and Tainung 1 and Calimosa, of the Formosa heterotic group. However, it is necessary to find new genotypes to increase the variety of materials that are available to producers (Luz et al., 2015). The fruits of the cultivars of the Solo group are small (500-700 g), have reddish pulp, and are preferred for export, whereas those of the Formosa group are medium-sized (1,000-1,500 g) and have reddish-orange pulp (Oliveira et al., 2012). The hybrids of the Formosa group have been gaining ground in the domestic and foreign markets, with 
growth in exports to Europe, Canada, and the United States (Reis et al., 2015).

Papaya blooms and produces fruits continuously for up to two years after reaching reproductive maturity (Martelleto et al., 2013). Despite this, floral behavior, which is highly sensitive to environmental factors, may negatively affect fruit production, leading to sexual reversion, carpelloidy, and pentandry (Damasceno Júnior et al., 2008). Furthermore, factors such as cultivar, water regime, temperature, incidence of pests and diseases, light exposure, and fruit maturity at harvest markedly affect fruit quality (Moretti et al., 2010). When comparing different cultivars, Reis et al. (2015) observed variations in the morphological and physicochemical characteristics of the fruits, which allowed identifying the best papaya genotypes of the Solo and Formosa groups. However, these authors did not consider the variation of these characteristics within each heterotic group and throughout the production cycle.

The objective of this work was to evaluate the productivity and quality of papaya fruits of the Solo (12 genotypes) and Formosa (9 genotypes) heterotic groups over two harvest seasons.

\section{Materials and Methods}

The experiment was carried out in a commercial papaya crop in the municipality of Pinheiros $\left(18^{\circ} 30^{\prime} 59^{\prime \prime} \mathrm{S}, 40^{\circ} 17^{\prime} 38^{\prime \prime} \mathrm{W}\right)$, in the state of Espírito Santo, Brazil. According to Köppen's classification, the climate is a tropical monsoon (Am), with an annual mean air temperature of $23.6^{\circ} \mathrm{C}$ and an annual mean rainfall of 1,308 $\mathrm{mm}$ (Alvares et al., 2013).

The chemical characterization of the soil at $0-20 \mathrm{~cm}-$ depth showed (Silva, 2009): $\mathrm{pH}\left(\mathrm{H}_{2} \mathrm{O}\right) 5.4$ (ratio 1:2.5); $85 \mathrm{mg} \mathrm{dm}{ }^{-3} \mathrm{P} ; 45 \mathrm{mg} \mathrm{dm}{ }^{-3} \mathrm{~K} ; 0.3 \mathrm{cmol}_{\mathrm{c}} \mathrm{dm}^{-3} \mathrm{Mg}$; $0.3 \mathrm{cmol}_{\mathrm{c}} \mathrm{dm}^{-3} \mathrm{Al} ; 2.5 \mathrm{cmol}_{\mathrm{c}} \mathrm{dm}^{-3} \mathrm{H}+\mathrm{Al}$; sum of bases of $1.4 \mathrm{cmol}_{\mathrm{c}} \mathrm{dm}^{-3}$; effective cation exchange capacity of $1.7 \mathrm{cmol}_{\mathrm{c}} \mathrm{dm}^{-3}$; base saturation of $36.1 \%$; and $1.5 \mathrm{dag}$ $\mathrm{dm}^{-3}$ organic matter. The Mehlich-1 method was used to extract $\mathrm{P}$ and $\mathrm{K}$, and $1 \mathrm{~mol} \mathrm{~L}^{-1} \mathrm{KCl}$ to obtain $\mathrm{Mg}$ and Al. Planting and topdressing fertilization were carried out according to Prezotti et al. (2007).

The seedlings were grown in the Bioplant Plus commercial substrate (Bioplant Agrícola Ltda., Nova Ponte, MG, Brazil), composed of coconut fiber and powder, pine bark, vermiculite, rice husks, and nutrients.
At 30 days after sowing, on 11/15/2012, the seedlings were transplanted - three per hole - to a previously prepared area. Sexing was performed after the emergence of floral buds, and one hermaphrodite plant was kept per hole. The used spacing was $3.50 \times 1.80 \mathrm{~m}$, and the plants were irrigated using a central pivot according to the crop's needs. The planting area was monitored in order to eliminate plants with symptoms of viral pathogens. The other crop treatments were carried out following the recommendations in the literature (Martins \& Costa, 2003).

Twenty-one papaya genotypes were evaluated: 12 of the Solo heterotic group and 9 of the Formosa heterotic group (Table 1). The experimental design was a randomized complete block, with five replicates and six plants per plot. For evaluation, the period of fruit production was subdivided into two seasons: winter, in which the fruits were harvested between June and August 2013 (210-300 days after planting); and summer, in which the fruits were harvested from January to March 2014 (450-540 days after planting). A mark was made in the fruiting region of each plant to distinguish the fruits developed in each season. In winter, the mean air temperature was $21.9^{\circ} \mathrm{C}$, with a minimum of $13.4^{\circ} \mathrm{C}$; the mean air humidity was $78 \%$; and the cumulative rainfall was $55.2 \mathrm{~mm}$. In summer, the mean air temperature was $24.9^{\circ} \mathrm{C}$, with a maximum of $34.2^{\circ} \mathrm{C}$; the mean air humidity was $78.9 \%$; and the cumulative rainfall was $301.4 \mathrm{~mm}$ (Incaper, 2015).

The following characteristics were evaluated in both harvest seasons: number of commercial fruits (NCF); number of deformed fruits (NDF); production of fruits per plant $(\mathrm{PP})$, in kilograms; fruit weight $(\mathrm{FW})$, in grams per fruit; fruit length (FL), in centimeters; fruit diameter (FD), also in centimeters; pulp thickness (PT), in centimeters; soluble solids (SS) contents, measured in ${ }^{\circ}$ Brix; titratable acidity (TA), expressed in grams of citric acid per $100 \mathrm{~g}$ of juice; and the SS/ TA ratio.

Three plants were sampled per plot to determine the $\mathrm{NCF}$ and the NDF. For the other variables, five fruits per plot - harvested at stage 2 of maturation, when $25 \%$ of the surface was yellow - were assessed, according to the systems approach (Martins \& Costa, 2003). The fruits were kept under the counter at $20 \pm 1^{\circ} \mathrm{C}$ prior to the physicochemical analyzes.

The data were subjected to the combined analysis of variance, in which each phenotypic observation can 
be described by the statistical model: $Y_{i j k}=\mu+G_{i}+A_{j}$ $+\mathrm{GA}_{\mathrm{ij}}+\mathrm{B} / \mathrm{A}_{\mathrm{jk}}+\mathrm{e}_{\mathrm{ijk}}$, in which $\mu$ is the general mean; $\mathrm{G}_{\mathrm{i}}$ is the effect of the $i$-th genotype; $A_{j}$ is the effect of the $\mathrm{j}$-th environment; $\mathrm{GA}_{\mathrm{ij}}$ is the effect of the interaction of the $\mathrm{i}$-th genotype with the $\mathrm{j}$-th environment; $\mathrm{B} / \mathrm{A}_{\mathrm{jk}}$ is the effect of the k-th block within the j-th environment; and $\mathrm{e}_{\mathrm{ijk}}$ is the random error. The genotype was considered as fixed, and the other effects of the model as random.

After the combined analysis of variance, the genotype $\mathrm{x}$ environment interactions were broken down, and the genotypic determination coefficient $\left(\mathrm{H}^{2}\right)$ and the coefficient of variation $(\mathrm{CV})$ were estimated. In each harvest season, the means were grouped by the Scott-Knott test, at 5\% probability. The differences between the means of each genotype for both harvest seasons were evaluated by the t-test, also at 5\% probability. The Genes software (Cruz, 2013) was used for the data analysis.

Table 1. Evaluated genetic papaya (Carica papaya) materials, type of cultivar, and supplier institution.

\begin{tabular}{ccc}
\hline Genetic material & Type of cultivar & Supplier institution ${ }^{(1)}$ \\
\hline Solo group & & \\
H 10-60 & Solo x Solo hybrid & CNPMF \\
H 26-60 & Solo x Solo hybrid & CNPMF \\
H 36-45 & Hybrid & CNPMF \\
L 06-08 & Line & CNPMF \\
L 47-P8 & Line & CNPMF \\
L 54-08 & Line & CNPMF \\
L 78-08 & Line & CNPMF \\
UC 13 & Solo x Solo hybrid & Uenf/Caliman \\
UC 14 & Solo x Solo hybrid & Uenf/Caliman \\
UC 15 & Solo x Solo hybrid & Uenf/Caliman \\
UC 16 & Solo x Solo hybrid & Uenf/Caliman \\
Golden & Line & Caliman \\
\hline Formosa group & & \\
L 10-08 & Line & CNPMF \\
UC 03 & Formosa x Solo hybrid & Uenf/Caliman \\
UC 10 & Formosa x Formosa hybrid & Uenf/Caliman \\
UC 11 & Formosa x Solo hybrid & Uenf/Caliman \\
UC 12 & Formosa x Solo x Formosa & Uenf/Caliman \\
& hybrid & \\
Rubi Incaper 511 & Line & Incaper \\
EW Sinja & Hybrid & East-West Seed \\
EW 2747 & Hybrid & East-West Seed \\
Tainung 1 & Hybrid & Takii do Brasil Ltda. \\
\hline
\end{tabular}

(1)CNPMF, Embrapa Mandioca e Fruticultura; Uenf/Caliman, Universidade Estadual do Norte Fluminense Darcy Ribeiro/Caliman Agrícola S/A; Incaper, Instituto Capixaba de Pesquisa, Assistência Técnica e Extensão Rural; and East-West Seed, East-West Seed International Ltda.

\section{Results and Discussion}

An interaction was observed between genotype and harvest season for PT, SS contents, TA, and the SS/TA ratio in the Solo heterotic group, as well as for NCF, NDF, and SS contents in the Formosa heterotic group. Between harvest seasons, differences were found for NCF, production per plant, FW, and PT, in Formosa group (Table 2).

Most variables differed according to harvest seasons and not to the harvest season $\mathrm{x}$ genotypes interactions. This shows that, although the environmental variations affected the studied characteristics, they did not change the classification of the genotypes, i.e., the interaction was simple. This type of interaction facilitates the work of the breeder, because it allows the recommendation of a single genetic material for different harvest seasons (Cruz et al., 2012). Luz et al. (2015) reported a strong interaction between genotype and harvest season for SS contents, NDF, NCF, FW, and PP, which can be explained by the combined evaluation of Solo and Formosa hybrids and by the greater number of harvests.

The genotypes of the Solo group were more sensitive to environmental variations than those of the Formosa group. This may be associated with the nature of the genotypes in each group: the Formosa group showed greater genetic uniformity, since there were only two lines and the other cultivars were all hybrids (Table 1).

No differences were observed for production and physicochemical characteristics (SS contents, TA, and the SS/TA ratio) between the genotypes of the Solo group, nor for NDF, PP, FD, SS contents, and the SS/ TA ratio between the genotypes of the Formosa group. However, for the other characteristics of commercial interest, such as NCF, FW, and PT, it was possible to identify materials that would meet the demands of the consumer (Table 2).

For the genotypes of the Solo group, the mean NCF was 27.50 , with each fruit weighing $591.75 \mathrm{~g}$, which represented a production per plant of $16.50 \mathrm{~kg}$. The mean value of SS contents was $13.66^{\circ} \mathrm{Brix}$, TA was $0.098 \%$ citric acid, and the SS/TA ratio was 145.99 (Table 2). These values agree with those obtained by Pinto et al. (2013a) and Reis et al. (2015), except for fruit weight, which was lower in the present study, but compatible with that of traditional Solo cultivars (Oliveira \& Vitória, 2011; Costa et al., 2013). 
For the genotypes of the Formosa group, the mean number of fruits was 16.12 , each weighing $1,298.82 \mathrm{~g}$, and plant production per plant was of $20.37 \mathrm{~kg}$. The mean values of SS contents $\left(13.01{ }^{\circ}\right.$ Brix) and of the $\mathrm{SS} / \mathrm{TA}$ ratio (135.85) were lower than those of the Solo genotypes (Table 2). These values are very close to those found for the same physical and physicochemical characteristics of fruits from the Tainung 1 and Sekati cultivars, respectively, produced in the west of the state of Bahia, Brazil (Yamanishi et al., 2006). It is important to highlight that, since, in the present work, the means for number of fruits and production were obtained for each harvest season, they do not represent the total productivity of the genotypes.

The CV values ranged from $5.46 \%$ for SS contents to $61.19 \%$ for PP in the Solo group, and from $6.05 \%$ for SS contents to $51.94 \%$ for NDF in the Formosa group (Table 2). These values were higher than those reported by Oliveira et al. (2010) and Reis et al. (2015). However, when considering characteristics of great phenotypic variation, the $\mathrm{CV}$ values were acceptable for papaya (Pinto et al., 2013a, 2013b) and allowed identifying differences between treatments.
$\mathrm{H}^{2}$ was greater than $70 \%$ for six variables analyzed in the Solo group and five in the Formosa group. The $\mathrm{H}^{2}$ values obtained for PP (50.49\%) and TA (37.95\%) in the Solo group, and for FD (16.81\%) and the SS/TA ratio (35.45\%) in the Formosa group were considered low. Silva et al. (2008) observed heritability values between 28 and $86 \%$ for PP, whereas Pinto et al. (2013a) reported values of $2 \%$ for FD and $0 \%$ for SS contents. Both heritability and $\mathrm{H}^{2}$, although not identical parameters, express how much of the variation observed is inheritable. Low heritability estimates can be attributed to the narrow genetic base of the population, which reduces the available genetic variability (Pinto et al., 2013a), as well as the effects of climate and of the nutritional conditions of the crop on fruit development (Moretti et al., 2010).

The analysis of the means of the genetic material of the Solo group showed that the NCF was higher for the summer harvest, except for 'L 47-P', which did not differ between seasons. There was an increase of 160 , 151 , and $136 \%$ in the NCF for the 'UC 16', 'H 26-60', and 'UC 14' from one season to the other (Table 3). For the NDF, only cultivars H 10-60, H 36-45, L 78-08, and Golden showed differences between harvest seasons, with lower values in winter.

Table 2. Combined analysis of variance, mean, coefficient of variation $(\mathrm{CV})$, and genotypic determination coefficient $\left(\mathrm{H}^{2}\right)$ of ten characteristics of papaya (Carica papaya) fruits from 12 genotypes of the Solo group and 9 genotypes of the Formosa group evaluated in field conditions in the municipality of Pinheiros, in the state of Espírito Santo, Brazil ${ }^{(1)}$.

\begin{tabular}{|c|c|c|c|c|c|c|c|c|c|c|c|}
\hline \multirow[t]{2}{*}{ Source of variation } & \multirow[t]{2}{*}{$\mathrm{DF}$} & \multicolumn{10}{|c|}{ Mean square } \\
\hline & & $\mathrm{NCF}$ & $\mathrm{NDF}$ & PP & FW & FL & FD & $\mathrm{PT}$ & SS & $\mathrm{TA}$ & $\mathrm{SS} / \mathrm{TA}$ ratio \\
\hline & & \multicolumn{10}{|c|}{ Solo group } \\
\hline Block & 8 & 157.93 & 71.14 & 77.39 & $13,633.48$ & 1.14 & 0.60 & 0.01 & 3.74 & 0.0005 & 641.60 \\
\hline Genotype (G) & 11 & $338.16^{*}$ & $99.83^{*}$ & 172.87 & $189,090.51^{*}$ & $39.86^{*}$ & $3.73^{*}$ & $0.25^{*}$ & 2.86 & 0.0004 & 351.79 \\
\hline Harvest season (S) & 1 & $11,027.35^{*}$ & $710.44^{*}$ & $6,049.91 *$ & $315,832.55^{*}$ & $45.68^{*}$ & $4.86^{*}$ & 0.21 & $21.99 *$ & 0.0020 & 230.71 \\
\hline $\mathrm{G} \times \mathrm{S}$ interaction & 11 & 96.85 & 32.92 & 85.58 & $21,304.49$ & 3.57 & 0.59 & $0.29 *$ & $1.20 *$ & $0.0003 *$ & $692.80^{*}$ \\
\hline$\underline{\text { Residue }}$ & 49 & 113.78 & 20.57 & 102.03 & $17,201.17$ & 2.39 & 0.43 & 0.03 & 0.56 & 0.0001 & 274.64 \\
\hline Mean & & 27.50 & 9.56 & 16.50 & 591.75 & 15.66 & 8.73 & 2.35 & 13.66 & 0.098 & 145.99 \\
\hline $\mathrm{CV}(\%)$ & & 38.80 & 47.43 & 61.19 & 22.16 & 9.86 & 7.52 & 7.93 & 5.46 & 12.07 & 11.35 \\
\hline \multirow[t]{2}{*}{$\mathrm{H}^{2}(\%)$} & & 71.36 & 67.02 & 50.49 & 88.73 & 91.05 & 84.05 & 78.78 & 58.02 & 37.95 & 96.93 \\
\hline & & \multicolumn{10}{|c|}{ Formosa group } \\
\hline Block & 8 & 79.17 & 24.03 & 155.60 & $181,921.81$ & 13.93 & 21.76 & 0.15 & 0.36 & 0.0001 & 484.07 \\
\hline Genotype & 8 & $383.14^{*}$ & 88.75 & 363.82 & $808,098.69^{*}$ & $26.62 *$ & 37.01 & $0.60 *$ & 7.65 & $0.0010^{*}$ & 960.21 \\
\hline Season & 1 & $2,700.43^{*}$ & 108.86 & $6,751.68 *$ & $2,737,644.01^{*}$ & 72.09 & 49.82 & $2.12 *$ & 0.01 & 0.0001 & 76.58 \\
\hline $\mathrm{G} \times \mathrm{S}$ interaction & 8 & $92.49 *$ & $37.64^{*}$ & 132.28 & $151,829.26$ & 5.23 & 30.79 & 0.07 & $3.08^{*}$ & 0.0002 & 619.86 \\
\hline Residue & 64 & 28.77 & 7.30 & 81.84 & $111,816.88$ & 7.73 & 21.57 & 0.06 & 0.62 & 0.0002 & 305.73 \\
\hline Mean & & 16.12 & 5.20 & 20.37 & $1,298.82$ & 22.26 & 11.40 & 2.88 & 13.01 & 0.10 & 135.85 \\
\hline$\overline{C V}(\%)$ & & 33.27 & 5.20 & 44.42 & 25.75 & 12.50 & 40.73 & 8.60 & 6.05 & 12.18 & 12.87 \\
\hline $\mathrm{H}^{2}(\%)$ & & 75.86 & 57.58 & 63.64 & 81.21 & 80.36 & 16.81 & 88.13 & 59.69 & 80.43 & 35.45 \\
\hline
\end{tabular}

${ }^{(1)} \mathrm{DF}$, degrees of freedom; NCF, number of commercial fruits; NDF, number of deformed fruits; PP, production of fruits per plant (kg); FW, fruit weight (g); FL, fruit length $(\mathrm{cm})$; FD, fruit diameter $(\mathrm{cm})$; PT, pulp thickness $(\mathrm{cm})$; SS, soluble solids contents $\left({ }^{\circ}\right.$ Brix $)$; and TA, titratable acidity $($ grams of citric acid per $100 \mathrm{~g})$. $*$ Significant by the F-test, at $5 \%$ probability. 
The summer harvest provided a higher NCF and NDF (Table 3), as observed by Silva et al. (2007). Martelleto et al. (2011) evaluated the floral behavior of papaya in four cropping systems, and reported that the environmental and phenological conditions favorable to the production of normal fruits and carpeloids were the same, which confirms that there is a positive correlation between these variables.

Summer harvest provided greater production per plant, except for 'L 47-P8', 'L 54-08', 'UC 15', and 'Golden', which showed the same behavior in both harvests. The Golden cultivar was grouped with the genotypes with lower PP and FW in the two harvest seasons. This reinforces the results obtained by Pinto et al. (2013a, 2013b), who observed the degeneration of the Golden cultivar due to the indiscriminate production of seeds, which causes the loss of its original characteristics.
PT was slightly affected by harvest season, except for the L 06-08 line, which showed the highest mean in summer, and for the UC 14 hybrid, which had the highest mean in winter, justifying the significance of the interaction (Table 3). In the winter harvest, PT varied greatly among genotypes, as reported by Luz et al. (2015). In summer, 'L 54-08', 'UC 14', and 'Golden' had the lowest means, differing from the other genotypes, which is in alignment with Reis et al. (2015), who found low variability for this characteristic among the evaluated genotypes. PT is an important quality attribute because it indicates higher yield (Luz et al., 2015); moreover, fruits with a lower PT, have a larger internal cavity, being more susceptible to losses during transport and storage (Oliveira et al., 2010). Therefore, the greater the PT, the better the acceptance of the fruits by the market and industry.

Table 3. Grouping of the means of ten characteristics of papaya (Carica papaya) fruits from 12 genotypes of the Solo group evaluated over two harvest seasons in the municipality of Pinheiros, in the state of Espírito de Santo, Brazil ${ }^{(1)}$.

\begin{tabular}{|c|c|c|c|c|c|c|c|c|c|c|}
\hline \multirow[t]{2}{*}{ Genotype } & \multicolumn{2}{|c|}{$\mathrm{NCF}$} & \multicolumn{2}{|c|}{ NDF } & \multicolumn{2}{|c|}{$\mathrm{PP}$} & \multicolumn{2}{|c|}{ FW } & \multicolumn{2}{|c|}{ FL } \\
\hline & Winter & Summer & Winter & Summer & Winter & Summer & Winter & Summer & Winter & Summer \\
\hline H 10-60 & $15.80 \mathrm{Bb}$ & $33.33 \mathrm{Ab}$ & $7.40 \mathrm{Bb}$ & $18.87 \mathrm{Aa}$ & $6.16 \mathrm{Bc}$ & $23.93 \mathrm{Aa}$ & $389.74 \mathrm{Bc}$ & $654.54 \mathrm{Aa}$ & $12.64 \mathrm{Bc}$ & $15.96 \mathrm{Ab}$ \\
\hline Н 26-60 & $15.53 \mathrm{Bb}$ & $38.93 \mathrm{Aa}$ & $6.00 \mathrm{Ab}$ & $11.33 \mathrm{Ab}$ & $8.59 \mathrm{Bc}$ & $27.88 \mathrm{Aa}$ & $576.21 \mathrm{Ab}$ & 694.02Aa & $14.88 \mathrm{Ab}$ & $16.44 \mathrm{Ab}$ \\
\hline Н $36-45$ & $17.40 \mathrm{Bb}$ & $31.87 \mathrm{Ab}$ & 7.79Bb & $14.27 \mathrm{Aa}$ & $12.06 \mathrm{Ba}$ & $24.26 \mathrm{Aa}$ & $708.62 \mathrm{Aa}$ & $772.86 \mathrm{Aa}$ & $18.57 \mathrm{Aa}$ & 17.67Aa \\
\hline L 06-08 & $17.80 \mathrm{Bb}$ & $40.40 \mathrm{Aa}$ & $7.80 \mathrm{Ab}$ & $11.60 \mathrm{Ab}$ & $9.77 \mathrm{Bb}$ & 28.99Aa & $556.78 \mathrm{Bb}$ & 728.58Aa & $15.99 \mathrm{Bb}$ & $18.41 \mathrm{Aa}$ \\
\hline L 47-P8 & $13.20 \mathrm{Ab}$ & $22.67 \mathrm{Ab}$ & $4.87 \mathrm{Ab}$ & $10.13 \mathrm{Ab}$ & $6.61 \mathrm{Ac}$ & $15.20 \mathrm{Ab}$ & $512.54 \mathrm{Ab}$ & 661.81Aa & $15.80 \mathrm{Ab}$ & $17.65 \mathrm{Aa}$ \\
\hline L 54-08 & $12.60 \mathrm{Bb}$ & $26.73 \mathrm{Ab}$ & $13.73 \mathrm{Aa}$ & $19.20 \mathrm{Aa}$ & $5.17 \mathrm{Ac}$ & $13.87 \mathrm{Ab}$ & $425.88 \mathrm{Ac}$ & $521.64 \mathrm{Ab}$ & $12.41 \mathrm{Ac}$ & $14.08 \mathrm{Ac}$ \\
\hline L 78-08 & $23.80 \mathrm{Ba}$ & $53.47 \mathrm{Aa}$ & 7.40Bb & $16.13 \mathrm{Aa}$ & $9.46 \mathrm{Bb}$ & 29.31Aa & $396.70 \mathrm{Ac}$ & $548.44 \mathrm{Ab}$ & $13.53 \mathrm{Ac}$ & $15.45 \mathrm{Ab}$ \\
\hline UC 13 & $18.07 \mathrm{Bb}$ & 40.67Aa & $6.47 \mathrm{Ab}$ & $7.47 \mathrm{Ab}$ & $10.52 \mathrm{Bb}$ & 27.39Aa & $576.54 \mathrm{Ab}$ & 684.08Aa & $15.42 \mathrm{Ab}$ & $16.40 \mathrm{Ab}$ \\
\hline UC 14 & $19.00 \mathrm{Bb}$ & $44.80 \mathrm{Aa}$ & $4.20 \mathrm{Ab}$ & $9.73 \mathrm{Ab}$ & $12.54 \mathrm{Ba}$ & $24.72 \mathrm{Aa}$ & 646.44Aa & $557.56 \mathrm{Ab}$ & $15.32 \mathrm{Ab}$ & $15.44 \mathrm{Ab}$ \\
\hline UC 15 & $20.47 \mathrm{Ba}$ & $32.07 \mathrm{Ab}$ & 7.27Ab & $5.40 \mathrm{Ab}$ & $14.59 \mathrm{Aa}$ & $22.41 \mathrm{Aa}$ & 713.73Aa & $730.30 \mathrm{Aa}$ & 17.87Aa & $17.81 \mathrm{Aa}$ \\
\hline UC 16 & $14.53 \mathrm{Bb}$ & $37.73 \mathrm{Aa}$ & $5.67 \mathrm{Ab}$ & $6.27 \mathrm{Ab}$ & $10.08 \mathrm{Bb}$ & $33.06 \mathrm{Aa}$ & $701.10 \mathrm{Ba}$ & 868.58Aa & $16.62 \mathrm{Ab}$ & $18.34 \mathrm{Aa}$ \\
\hline \multirow[t]{3}{*}{ Golden } & $26.73 \mathrm{Ba}$ & $42.33 \mathrm{Aa}$ & $6.93 \mathrm{Bb}$ & $13.53 \mathrm{Aa}$ & $7.31 \mathrm{Ac}$ & $12.24 \mathrm{Ab}$ & $281.06 \mathrm{Ac}$ & $294.20 \mathrm{Ac}$ & $11.50 \mathrm{Ac}$ & $11.63 \mathrm{Ad}$ \\
\hline & \multicolumn{2}{|c|}{ FD } & \multicolumn{2}{|c|}{ PT } & \multicolumn{2}{|c|}{ SS } & \multicolumn{2}{|c|}{ TA } & \multicolumn{2}{|c|}{ SS/TA ratio } \\
\hline & Winter & Summer & Winter & Summer & Winter & Summer & Winter & Summer & Winter & Summer \\
\hline H 10-60 & $8.12 \mathrm{Bb}$ & $9.06 \mathrm{Aa}$ & $2.14 \mathrm{Ac}$ & $2.34 \mathrm{Aa}$ & $13.73 \mathrm{Aa}$ & $13.64 \mathrm{Ab}$ & $0.094 \mathrm{Aa}$ & $0.108 \mathrm{Aa}$ & 154.17Aa & $137.20 \mathrm{Ab}$ \\
\hline Н 26-60 & $8.85 \mathrm{Aa}$ & $9.45 \mathrm{Aa}$ & $2.33 \mathrm{Ab}$ & $2.44 \mathrm{Aa}$ & $12.10 \mathrm{Ba}$ & $13.06 \mathrm{Ab}$ & $0.084 \mathrm{Aa}$ & $0.096 \mathrm{Ab}$ & $149.92 \mathrm{Aa}$ & $138.83 \mathrm{Ab}$ \\
\hline Н 36-45 & $8.92 \mathrm{Aa}$ & $9.44 \mathrm{Aa}$ & $2.64 \mathrm{Aa}$ & $2.54 \mathrm{Aa}$ & $13.02 \mathrm{Aa}$ & $13.87 \mathrm{Ab}$ & $0.092 \mathrm{Aa}$ & $0.102 \mathrm{Aa}$ & $146.98 \mathrm{Aa}$ & $139.04 \mathrm{Ab}$ \\
\hline L 06-08 & $8.44 \mathrm{Ba}$ & 8.98Aa & $2.44 \mathrm{Bb}$ & $2.69 \mathrm{Aa}$ & $12.96 \mathrm{Aa}$ & 13.18Ab & $0.092 \mathrm{Aa}$ & $0.090 \mathrm{Ab}$ & $152.39 \mathrm{Aa}$ & $151.77 \mathrm{Aa}$ \\
\hline L 47-P8 & $8.20 \mathrm{Ab}$ & $9.06 \mathrm{Aa}$ & $2.27 \mathrm{Ac}$ & $2.47 \mathrm{Aa}$ & $13.06 \mathrm{Ba}$ & $15.05 \mathrm{Aa}$ & $0.106 \mathrm{Aa}$ & $0.094 \mathrm{Ab}$ & $129.03 \mathrm{Bb}$ & $165.45 \mathrm{Aa}$ \\
\hline L 54-08 & $8.48 \mathrm{Aa}$ & $8.61 \mathrm{Ab}$ & $2.01 \mathrm{Ad}$ & $2.04 \mathrm{Ab}$ & $13.80 \mathrm{Aa}$ & $14.36 \mathrm{Aa}$ & $0.098 \mathrm{Aa}$ & $0.096 \mathrm{Ab}$ & $145.15 \mathrm{Aa}$ & $159.61 \mathrm{Aa}$ \\
\hline L 78-08 & $7.82 \mathrm{Ab}$ & $8.58 \mathrm{Ab}$ & $2.24 \mathrm{Ac}$ & $2.46 \mathrm{Aa}$ & 13.10Aa & $13.18 \mathrm{Ab}$ & $0.084 \mathrm{Aa}$ & $0.088 \mathrm{Ab}$ & $159.22 \mathrm{Aa}$ & $153.93 \mathrm{Aa}$ \\
\hline UC 13 & 8.78Aa & 9.17Aa & $2.39 \mathrm{Ab}$ & $2.48 \mathrm{Aa}$ & $13.56 \mathrm{Ba}$ & $14.63 \mathrm{Aa}$ & $0.092 \mathrm{Ba}$ & $0.110 \mathrm{Aa}$ & $150.72 \mathrm{Aa}$ & $135.87 \mathrm{Ab}$ \\
\hline UC 14 & $9.22 \mathrm{Aa}$ & $8.40 \mathrm{Ab}$ & $2.58 \mathrm{Aa}$ & $2.18 \mathrm{Bb}$ & $13.02 \mathrm{Ba}$ & $14.40 \mathrm{Aa}$ & $0.086 \mathrm{Ba}$ & $0.110 \mathrm{Aa}$ & $156.01 \mathrm{Aa}$ & $132.87 \mathrm{Bb}$ \\
\hline UC 15 & 9.19Aa & $9.26 \mathrm{Aa}$ & $2.33 \mathrm{Ab}$ & $2.46 \mathrm{Aa}$ & $14.42 \mathrm{Aa}$ & $14.56 \mathrm{Aa}$ & $0.100 \mathrm{Ba}$ & $0.116 \mathrm{Aa}$ & $146.54 \mathrm{Aa}$ & $131.49 \mathrm{Ab}$ \\
\hline UC 16 & $9.20 \mathrm{Aa}$ & 9.98Aa & $2.45 \mathrm{Ab}$ & $2.56 \mathrm{Aa}$ & $13.00 \mathrm{Ba}$ & $14.30 \mathrm{Aa}$ & $0.088 \mathrm{Aa}$ & $0.102 \mathrm{Aa}$ & $148.73 \mathrm{Aa}$ & $148.53 \mathrm{Aa}$ \\
\hline Golden & 7.16Ac & 7.24Ac & 1.98Ad & $1.84 \mathrm{Ab}$ & $13.07 \mathrm{Ba}$ & 14.89Aa & $0.106 \mathrm{Aa}$ & $0.108 \mathrm{Aa}$ & $129.62 \mathrm{Ab}$ & $140.59 \mathrm{Ab}$ \\
\hline
\end{tabular}

(1)Means followed by equal letters, uppercase in the lines and lowercase in the columns, do not differ by the $\mathrm{t}$ and Scott-Knott tests, respectively, at $5 \%$ probability. NCF, number of commercial fruits; NDF, number of deformed fruits; PP, production of fruits per plant (kg); FW, fruit weight (g); FL, fruit length (cm); FD, fruit diameter (cm); PT, pulp thickness (cm); SS, soluble solids contents ( ${ }^{\circ}$ Brix); TA, titratable acidity (grams of citric acid per 100 g); winter, 210-300 days after planting; and summer, 450-540 days after planting. 
There were interactions between genotype and harvest season for SS contents, TA, and the SS/TA ratio, confirming that the chemical characteristics of the fruits are among the most affected by climatic conditions (Moretti et al., 2010). No differences were found in SS contents between the genotypes in winter. In summer, the hybrids developed by Universidade Estadual do Norte Fluminense Darcy Ribeiro in partnership with Caliman Agrícola S/A (Uenf/Caliman), as well as the 'L 47-P8', 'L 54-08', and 'Golden', stood out because they had ${ }^{\circ}$ Brix values between 14.30 ('UC 16') and 15.05 ('L 47-P8'). These values were high compared with those obtained by Pinto et al. (2013b) - between 9.3 and $11^{\circ}$ Brix, above the acceptable value by the fruit market for the Solo group, of approximately $11.5^{\circ}$ Brix (Fagundes \& Yamanishi, 2001).

With regard to SS contents and TA, no differences were observed between the genetic materials in winter. In summer, the highest TA values were obtained by the Uenf/Caliman hybrids and by 'Golden', 'H 36-45', and 'H 10-60'. For the SS/TA ratio, the lowest values were found for the Golden and L 47-P8 cultivars in winter, whereas, in summer, the lines from Embrapa Mandioca e Fruticultura and the UC 16 hybrid had the best means. It should be noted that the sweetest papaya fruits have low acidity and high SS values (Luz et al., 2015); and nitrogen and boron fertilizations are recommended for maximum SS contents (Brito Neto et al., 2011).

Regarding the cultivars of the Formosa group, the mean NCF was higher in summer, except for 'EW Sinja' and 'EW 2747', which did not differ between harvest seasons. However, no differences were observed between harvest seasons for the NDF, except for 'L 1008', which had the highest mean in summer (Table 4). According to Damasceno Júnior et al. (2008), the number of hermaphrodite flowers in papaya hybrids that produce commercial fruit significantly affect the environment, especially in summer; however, this was not the case in the present study. Intrapopulation variability, which confers greater rusticity and adaptive capacity, may have affected the results obtained for the evaluated genotypes.

When considering the general mean of all genotypes and harvest seasons, the ratio between the NDF and $\mathrm{NCF}$ was greater than $25 \%$ (Table 4 ), which would cause great losses to the producer. This reinforces the need to search for more efficient genotypes. Therefore, the UC 03 and Tainung 1 hybrids should be avoided in winter, and 'L 10-08' in summer because they have a higher NDF.

The PP values were higher in summer, except for the UC 03 and EW 2747 cultivars. However, 'Rubi Incaper 511' had higher yields in both harvests: in summer, it was superior to the other genotypes by more than $10 \mathrm{~kg}$ per plant, and in winter it was similar to UC 11, UC 12, and Tainung 1 (Table 4). It should be highlighted that 'Rubi Incaper 511' is an openpollination cultivar; therefore, it is possible to reuse its seeds and, consequently, to reduce production costs, increasing profits (Rubi Incaper 511, 2010).

Except for the UC 11, EW Sinja, and EW 2747 cultivars, FW was the same in both harvest seasons, and genotype clustering varied little in each environment (Table 4). The 'UC 10', 'EW Sinja', and 'EW 2747' also had the highest means in the two harvest seasons; however, they produced fruits weighing more than the commercial standard of 800 to $1,100 \mathrm{~g}$ (Costa et al., 2013).

For PT, although the harvest seasons affected the evaluated genotypes, the materials with the highest means were the same in both seasons, namely: 'Rubi Incaper 511', 'EW Sinja', and 'EW 2747' (Table 4). Along with 'UC 10', these same cultivars had the highest fruit weights in winter, which confirms the high positive correlation between these variables, as reported by Oliveira et al. (2010) and Reis et al. (2015).

There was no difference between harvest seasons regarding SS contents, except for the L 10-08 and Rubi Incaper 511 lines, which had the lowest means among the genotypes analyzed in winter (Table 4). This result reinforces the need to continue the papaya breeding program developed by Instituto Capixaba de Pesquisa, Assistência Técnica e Extensão Rural (Incaper), which seeks to improve the SS contents of 'Rubi Incaper 511'. However, in summer, the UC 03 hybrid stood out with a higher mean than that obtained by Luz et al. (2015), possibly because these authors assessed the SS contents at stage 1 of fruit ripening.

For TA and the SS/TA ratio, only 'EW 2747' differed between harvest seasons, with higher TA in summer and higher SS/TA ratio in winter (Table 4). With the exception of 'UC 10', in summer, the genotypes with the highest TA had the lowest SS/TA ratio or the inverse, due to the calculation of the SS/TA ratio and 
Table 4. Grouping of the means of ten characteristics of papaya (Carica papaya) fruits from nine genotypes of the Formosa group evaluated over two harvest seasons in the municipality of Pinheiros, in the state of Espírito Santo, Brazil ${ }^{(1)}$.

\begin{tabular}{|c|c|c|c|c|c|c|c|c|c|c|}
\hline \multirow[t]{2}{*}{ Genotype } & \multicolumn{2}{|c|}{$\mathrm{NCF}$} & \multicolumn{2}{|c|}{ NDF } & \multicolumn{2}{|c|}{$\mathrm{PP}$} & \multicolumn{2}{|c|}{ FW } & \multicolumn{2}{|c|}{ FL } \\
\hline & Winter & Summer & Winter & Summer & Winter & Summer & Winter & Summer & Winter & Summer \\
\hline 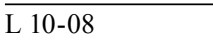 & $16.87 \mathrm{Ba}$ & $31.80 \mathrm{Aa}$ & $5.27 \mathrm{Bb}$ & $17.33 \mathrm{Aa}$ & $14.16 \mathrm{Bb}$ & $28.24 \mathrm{Ab}$ & $824.93 \mathrm{Ab}$ & $1,037.18 \mathrm{Ab}$ & $19.31 \mathrm{Ab}$ & $21.15 \mathrm{Ab}$ \\
\hline UC 03 & $8.07 \mathrm{Bc}$ & $21.20 \mathrm{Ab}$ & $7.80 \mathrm{Aa}$ & $10.27 \mathrm{Ab}$ & $8.62 \mathrm{Ab}$ & $20.00 \mathrm{Ab}$ & $1,053.06 \mathrm{Ab}$ & $945.22 \mathrm{Ab}$ & $20.74 \mathrm{Ab}$ & $19.41 \mathrm{Ab}$ \\
\hline UC 10 & $5.53 \mathrm{Bc}$ & $16.53 \mathrm{Ac}$ & $1.73 \mathrm{Ab}$ & $3.40 \mathrm{Ac}$ & $7.61 \mathrm{Bb}$ & $27.82 \mathrm{Ab}$ & $1,284.82 \mathrm{Aa}$ & $1,696.34 \mathrm{Aa}$ & $23.18 \mathrm{Aa}$ & $23.98 \mathrm{Aa}$ \\
\hline UC 11 & $7.73 \mathrm{Bc}$ & $21.00 \mathrm{Ab}$ & $3.33 \mathrm{Ab}$ & $2.93 \mathrm{Ac}$ & $8.93 \mathrm{Bb}$ & 34.09Aa & $1,107.38 \mathrm{Bb}$ & $1,545.92 \mathrm{Aa}$ & $22.64 \mathrm{Aa}$ & $25.68 \mathrm{Aa}$ \\
\hline UC 12 & $11.93 \mathrm{Bb}$ & $27.00 \mathrm{Aa}$ & $3.53 \mathrm{Ab}$ & $4.53 \mathrm{Ac}$ & $11.76 \mathrm{Bb}$ & $31.56 \mathrm{Aa}$ & $986.24 \mathrm{Ab}$ & $1,202.82 \mathrm{Ab}$ & $20.02 \mathrm{Ab}$ & $21.66 \mathrm{Ab}$ \\
\hline Rubi Incaper 511 & $20.40 \mathrm{Ba}$ & $29.27 \mathrm{Aa}$ & $3.80 \mathrm{Ab}$ & $5.26 \mathrm{Ac}$ & $24.33 \mathrm{Ba}$ & 41.94Aa & $1,185.08 \mathrm{Aa}$ & $1,456.06 \mathrm{Ab}$ & $22.91 \mathrm{Aa}$ & 25.37Aa \\
\hline EW Sinja & $5.66 \mathrm{Ac}$ & $11.27 \mathrm{Ac}$ & $3.13 \mathrm{Ab}$ & $5.53 \mathrm{Ac}$ & $7.70 \mathrm{Bb}$ & $24.01 \mathrm{Ab}$ & $1,484.44 \mathrm{Ba}$ & $2,120.80 \mathrm{Aa}$ & $20.72 \mathrm{Ab}$ & $22.34 \mathrm{Ab}$ \\
\hline EW 2747 & $9.73 \mathrm{Ab}$ & $7.93 \mathrm{Ac}$ & $3.00 \mathrm{Ab}$ & $2.80 \mathrm{Ac}$ & $11.88 \mathrm{Ab}$ & $15.41 \mathrm{Ab}$ & $1,200.21 \mathrm{Ba}$ & 1,923.64Aa & $20.76 \mathrm{Bb}$ & $24.49 \mathrm{Aa}$ \\
\hline \multirow[t]{3}{*}{ Tainung 1} & $9.87 \mathrm{Bb}$ & $28.40 \mathrm{Aa}$ & $5.33 \mathrm{Aa}$ & $4.67 \mathrm{Ac}$ & $10.35 \mathrm{Bb}$ & 38.16Aa & $993.58 \mathrm{Ab}$ & $1,331.10 \mathrm{Ab}$ & $21.96 \mathrm{Aa}$ & $24.29 \mathrm{Aa}$ \\
\hline & \multicolumn{2}{|c|}{ FD } & \multicolumn{2}{|c|}{ PT } & \multicolumn{2}{|c|}{ SS } & \multicolumn{2}{|c|}{$\mathrm{TA}$} & \multicolumn{2}{|c|}{ SS/TA ratio } \\
\hline & Winter & Summer & Winter & Summer & Winter & Summer & Winter & Summer & Winter & Winter \\
\hline 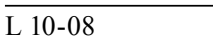 & $9.31 \mathrm{Aa}$ & $9.47 \mathrm{Aa}$ & $2.46 \mathrm{Ab}$ & $2.65 \mathrm{Ac}$ & $11.19 \mathrm{Bc}$ & $12.64 \mathrm{Ab}$ & $0.090 \mathrm{Ac}$ & $0.098 \mathrm{Ab}$ & $128.90 \mathrm{Ab}$ & $139.37 \mathrm{Aa}$ \\
\hline UC 03 & $13.86 \mathrm{Aa}$ & $10.07 \mathrm{Aa}$ & $2.61 \mathrm{Ab}$ & $2.62 \mathrm{Ac}$ & $14.18 \mathrm{Aa}$ & $14.62 \mathrm{Aa}$ & $0.102 \mathrm{Ab}$ & $0.114 \mathrm{Aa}$ & $140.72 \mathrm{Aa}$ & $133.05 \mathrm{Ab}$ \\
\hline UC 10 & $10.15 \mathrm{Aa}$ & $12.07 \mathrm{Aa}$ & $2.68 \mathrm{Bb}$ & $3.02 \mathrm{Ab}$ & $13.08 \mathrm{Ab}$ & $12.27 \mathrm{Ab}$ & $0.106 \mathrm{Ab}$ & $0.096 \mathrm{Ab}$ & $134.38 \mathrm{Ab}$ & $131.55 \mathrm{Ab}$ \\
\hline UC 11 & $9.85 \mathrm{Aa}$ & $11.07 \mathrm{Aa}$ & $2.62 \mathrm{Bb}$ & $2.99 \mathrm{Ab}$ & $14.80 \mathrm{Aa}$ & $12.76 \mathrm{Ab}$ & $0.124 \mathrm{Aa}$ & $0.116 \mathrm{Aa}$ & $120.60 \mathrm{Ab}$ & $114.99 \mathrm{Ab}$ \\
\hline UC 12 & $9.92 \mathrm{Aa}$ & $10.42 \mathrm{Aa}$ & $2.55 \mathrm{Bb}$ & $2.92 \mathrm{Ab}$ & $13.34 \mathrm{Ab}$ & $13.43 \mathrm{Ab}$ & $0.108 \mathrm{Ab}$ & $0.110 \mathrm{Aa}$ & $127.37 \mathrm{Ab}$ & $127.97 \mathrm{Ab}$ \\
\hline Rubi Incaper 511 & $10.20 \mathrm{Aa}$ & $10.64 \mathrm{Aa}$ & $2.84 \mathrm{Ba}$ & $3.21 \mathrm{Aa}$ & $10.90 \mathrm{Bc}$ & $12.42 \mathrm{Ab}$ & $0.086 \mathrm{Ac}$ & $0.086 \mathrm{Ab}$ & $129.74 \mathrm{Ab}$ & $151.62 \mathrm{Aa}$ \\
\hline EW Sinja & $12.03 \mathrm{Aa}$ & $14.23 \mathrm{Aa}$ & $3.10 \mathrm{Aa}$ & $3.34 \mathrm{Aa}$ & $12.93 \mathrm{Ab}$ & $12.53 \mathrm{Ab}$ & $0.096 \mathrm{Ac}$ & $0.092 \mathrm{Ab}$ & 141.39Aa & $143.22 \mathrm{Aa}$ \\
\hline EW 2747 & $10.81 \mathrm{Ba}$ & $20.42 \mathrm{Aa}$ & $2.94 \mathrm{Ba}$ & $3.57 \mathrm{Aa}$ & $13.72 \mathrm{Ab}$ & $13.30 \mathrm{Ab}$ & $0.094 \mathrm{Bc}$ & $0.114 \mathrm{Aa}$ & $155.38 \mathrm{Aa}$ & $119.01 \mathrm{Bb}$ \\
\hline Tainung 1 & $9.82 \mathrm{Aa}$ & $10.95 \mathrm{Aa}$ & $2.75 \mathrm{Ab}$ & $3.00 \mathrm{Ab}$ & $12.90 \mathrm{Ab}$ & $13.20 \mathrm{Ab}$ & $0.088 \mathrm{Ac}$ & $0.090 \mathrm{Ab}$ & $152.52 \mathrm{Aa}$ & $153.60 \mathrm{Aa}$ \\
\hline
\end{tabular}

${ }^{(1)}$ Means followed by equal letters, uppercase in the lines and lowercase in the columns, do not differ by the t and Scott-Knott tests, respectively, at $5 \%$ probability. NCF, number of commercial fruits; NDF, number of deformed fruits; PP, production of fruits per plant (kg); FW, fruit weight (g); FL, fruit length $(\mathrm{cm})$; FD, fruit diameter $(\mathrm{cm})$; PT, pulp thickness $(\mathrm{cm})$; SS, soluble solids contents ( ${ }^{\circ}$ Brix); TA, titratable acidity (grams of citric acid per $100 \mathrm{~g}$ ); winter, 210-300 days after planting; and summer, 450-540 days after planting.

to the higher correlation with TA, when compared with SS contents (Reis et al., 2015).

\section{Conclusions}

1. In the Solo group of papaya (Carica papaya), the $\mathrm{H}$ 36-45 and UC 15 hybrids show greater production and fruit weight in the two harvest seasons (winter and summer) evaluated, and have high soluble solids contents.

2. In the Formosa group, 'Rubi Incaper 511' stands out due to its greater productivity, higher number of commercial fruits, and lower number of deformed fruits in the two harvest seasons assessed.

\section{Acknowledgments}

To Mr. Carlito Covre, for providing the area and the input to carry out this work; to Embrapa Mandioca e Fruticultura, to Universidade Estadual do Norte Fluminense Darcy Ribeiro, and to Caliman Agrícola $\mathrm{S} / \mathrm{A}$, for providing the seeds for genetic evaluation; and to Conselho Nacional e Desenvolvimento Científico e Tecnológico (CNPq), for financial support.

\section{References}

ALVARES, C.A.; STAPE, J.L.; SENTELHAS, P.C.; GOLÇALVES, J.L. de M.; SPAROVEK, G. Köppen's climate classification map for Brazil. Meteorologische Zeitschrift, v.22, p.711-728, 2013. DOI: 10.1127/0941-2948/2013/0507.

BRITO NETO, J.F. de; PEREIRA, W.E.; CAVALCANTI, L.F.; ARAÚJO, R. da C.; LACERDA, J.S. de. Produtividade e qualidade de frutos de mamoeiro 'sunrise solo' em função de doses de nitrogênio e boro. Semina: Ciências Agrárias, v.32, p.69-80, 2011. DOI: 10.5433/1679-0359.2011v32n1p69.

COSTA, A. de F.S. da; DANTAS, J.L.L.; PEREIRA, M.G.; CATTANEO, L.F.; COSTA, A.N. da; MOREIRA, S.O. Botânica, melhoramento e variedades. Informe Agropecuário, v.34, p.1424, 2013.

CRUZ, C.D. GENES: a software package for analysis in experimental statistics and quantitative genetics. Acta Scientiarum. Agronomy, v.35, p.271-276, 2013. DOI: 10.4025/ actasciagron.v35i3.21251. 
CRUZ, C.D.; REGAZZI, A.J.; CARNEIRO, P.C.S. Modelos biométricos aplicados ao melhoramento genético. 4.ed. Viçosa: Ed. da UFV, 2012. v.1, 514p.

DAMASCENO JÚNIOR, P.C.; PEREIRA, T.N.S.; SILVA, F.F. da; VIANA, A.P.; PEREIRA, M.G. Comportamento floral de híbridos de mamoeiro (Carica papaya L.) avaliados no verão e na primavera. Revista Ceres, v.55, p.310-316, 2008.

FAGUNDES, G.R.; YAMANISHI, O.K. Características físicas e químicas de frutos de mamoeiro do grupo 'Solo' comercializados em 4 estabelecimentos de Brasília-DF. Revista Brasileira de Fruticultura, v.23, p.541-545, 2001. DOI: 10.1590/S010029452001000300018.

INCAPER. Instituto Capixaba de Pesquisa, Assistência Técnica e Extensão Rural. Boletins Agroclimáticos. Available at: $<$ http:// hidrometeorologia.incaper.es.gov.br/?pagina=bol $>$. Accessed on: Dec. 162015.

LUZ, L.N. da; PEREIRA, M.G.; BARROS, F.R.; BARROS, G. de B.; FERREGUETTI, G.A. Novos híbridos de mamoeiro avaliados nas condições de cultivo tradicional e no semiárido brasileiro. Revista Brasileira de Fruticultura, v.37, p.159-171, 2015. DOI: 10.1590/0100-2945-069/14.

MARTELLETO, L.A.P.; RIBEIRO, R. de L.D.; SUDOMARTELLETO, M.; VASCONCELLOS, M.A. da S.; PEREIRA, M.B. Expressão da esterilidade feminina e da carpeloidia em mamoeiro sob diferentes ambientes de cultivo protegido. Revista Brasileira de Fruticultura, v.33, p.1185-1193, 2011. DOI: 10.1590/S0100-29452011000400017.

MARTELLETO, L.A.P.; SUDO-MARTELLETO, M.; MACHADO, A.F.L.; VASCONCELLOS, M.A. da S. Manejo fitotécnico. Informe Agropecuário, v.34, n.275, p.29-37, 2013.

MARTINS, D. dos S.; COSTA, A. de F.S. da (Ed.). A cultura do mamoeiro: tecnologias de produção. Vitória: Incaper, 2003. 497p.

MORETTI, C.L.; MATTOS, L.M.; CALBO, A.G.; SARGENT, S.A. Climate changes and potential impacts on postharvest quality of fruit and vegetable crops: a review. Food Research International, v.43, p.1824-1832, 2010. DOI: 10.1016/j. foodres.2009.10.013.

OLIVEIRA, E.J. de; LIMA, D.S. de; LUCENA, R.S.; MOTTA, T.B.N.; DANTAS, J.L.L. Correlações genéticas e análise de trilha para número de frutos comerciais por planta em mamoeiro. Pesquisa Agropecuária Brasileira, v.45, p.855-862, 2010. DOI: 10.1590/S0100-204X2010000800011.

OLIVEIRA, E.J. de; OLIVEIRA, G.A.F; COSTA, J.L.; OLIVEIRA, V.J. dos S. de; DANTAS, A.C.V.L.; DANTAS, J.L.L.; PÁDUA, J.G. Genetic diversity and marker-assisted inbreeding in papaya. Scientia Horticulturae, v.147, p.20-28, 2012. DOI: 10.1016/j.scienta.2012.08.031.
OLIVEIRA, J.G. de; VITÓRIA, A.P. Papaya: nutritional and pharmacological characterization, and quality loss due to physiological disorders. An overview. Food Research International, v.44, p.1306-1313, 2011. DOI: 10.1016/j. foodres.2010.12.035.

PINTO, F. de O.; LUZ, L.N.; PEREIRA, M.G.; CARDOSO, D.L.; RAMOS, H.C.C. Metodologia dos modelos mistos para seleção combinada em progênies segregantes de mamoeiro. Revista Brasileira de Ciências Agrárias, v.8, p.211-217, 2013a. DOI: 10.5039/agraria.v8i2a2409.

PINTO, F. de O.; RAMOS, H.C.C.; CARDOSO, D.L.; LUZ, L.N. da; PEREIRA, M.G. Desenvolvimento de genótipos de mamoeiro tolerantes à mancha fisiológica. Revista Brasileira de Fruticultura, v.35, p.1101-1115, 2013b. DOI: 10.1590/S010029452013000400022.

PREZOTTI, L.C.; GOMES, J.A.; DADALTO, G.G.; OLIVEIRA, J.A. Manual de recomendação de calagem e adubação para o estado do Espírito Santo: $5^{\text {a }}$ aproximação. Vitória: Seea/Incaper/ Cedagro, 2007. 305p.

REIS, R.C.; VIANA, E. de S.; JESUS, J.L. de; DANTAS, J.L.L.; LUCENA, R.S. Caracterização físico-química de frutos de novos híbridos e linhagens de mamoeiro. Pesquisa Agropecuária Brasileira, v.50, p.210-217, 2015. DOI: 10.1590/S0100204X2015000300004.

'RUBI INCAPER 511': primeira variedade de mamão do grupo 'Formosa' para o Espírito Santo. Vitória: DCM/Incaper, 2010. (Incaper. Documentos, 187).

SILVA, F.C. da (Ed.). Manual de análises químicas de solos, plantas e fertilizantes. 2.ed. Brasília: Embrapa Informação Tecnológica, 2009. 627p.

SILVA, F.F. da; PEREIRA, M.G.; DAMASCENO JÚNIOR, P.C.; PEREIRA, T.N.S.; VIANA, A.P.; DAHER, R.F.; RAMOS, H.C.C.; FERREGUETTI, G.A. Evaluation of the sexual expression in a segregating $\mathrm{BC}_{1}$ papaya population. Crop Breeding and Applied Biotechnology, v.7, p.16-23, 2007. DOI: 10.12702/1984-7033. v07n01a03.

SILVA, F.F. da; PEREIRA, M.G.; RAMOS, H.C.C.; DAMASCENO JUNIOR, P.C.; PEREIRA, T.N.S.; VIANA, A.P.; DAHER, R.F.; FERREGUETTI, G.A. Estimation of genetic parameters related to morpho-agronomic and fruit quality traits of papaya. Crop Breeding and Applied Biotechnology, v.8, p.65-73, 2008. DOI: 10.12702/1984-7033. v08n01a09.

YAMANISHI, O.K.; MELLO, R.M. de; MARTINS, V.A.; LIMA, L.A. de; FAGUNDES, G.R. Comportamento do mamoeiro Sekati nas condições do oeste da Bahia. Revista Brasileira de Fruticultura, v.28, p.79-82, 2006. DOI: 10.1590/S010029452006000100023.

$\overline{\text { Received on June 2, } 2016 \text { and accepted on September 30, } 2016}$ 